\title{
The Personality of the Academic Librarian
}

\author{
BY PERRY D. MORRISON
}

COLLEGE AND UNIVERSITY LIBRARIANS tend to be highly intelligent with an outlook on life similar to that of members of other high-level occupations. On the whole, they are self-assured and by no means timid souls. However, they may lack initiative and-with perhaps even more serious consequence-tend to be deficient in supervisory qualities.

Lest unwarranted conclusions be drawn from the above statements, it should be further stated that this is a group profile. To describe a group is not to describe each individual in it. This is particularly true of librarians. They form an unusually heterogeneous group in personality make-up. There is no stereotype into which all, or even most, of them fall.

These generalizations are based on a personality inventory administered in 1958 to 676 academic librarians in all parts of the United States. The instrument used was the Ghiselli "Self Description Inventory," a device requiring each subject to choose the adjectives he feels best and least describe him. This relatively simple test has been shown to give a remarkably valid picture of the major tendencies in a group as large as this. ${ }^{1}$

Table 1 gives the scores of academic librarians on the personality traits measured, and compares them with the scores made by a representative sample of the general working population. It shows, for example, that the average librarian in the survey ranks in the upper quarter of the population in intelligence, in the

1 Edwin E. Ghiselli, "Self Description Inventory" (University of California, 1957), p. 7. See also E. E. Ghiselli, "The Forced-Choice Technique in Self-Description," Personnel Psychology, VII (Summer 1954), 201-08.
Dr. Morrison is Librarian of Sacramento State College.

upper third in occupational level, and in the lower half in initiative.

That the intelligence scores should be high is not surprising. It is virtually impossible for a group to have surmounted the educational hurdles required of academic librarians without being rich in intellectual ability. There is, however, an ironic twist to this: because intelligence is so abundant among these librarians, other, less common qualities determine the likelihood of an individual rising in the hierarchy of the profession.

Let the reader make of this what he will, intelligence does not, on the average, distinguish the executive from the ordinary librarian. Both groups are composed of persons of superior intellect.

Initiative, on the other hand, is relatively scarce among academic librarians and it does tend to distinguish the chiefs from the Indians. According to the compiler of the inventory, Edwin E. Ghiselli, persons with initiative are able to act independently, to develop "novel approaches to old problems," and to assume the risks involved. ${ }^{2}$ In all fairness, it must be said that many library positions do not require a great deal of initiative, but the tempo of change is quickening. What was adequate in the past may not be so in the future. For example, in the future it may not be sufficient for only half of the major executives in librarianship to possess a better-than-average measure of initiative. Similarly, the nonexecutives will be

${ }^{2}$ Ghiselli, "Self Description Inventory," p. 3. 
TABLE 1

MeAN SCORES ON GHiselli SELF-Description INVENTORY ExPRESSEd AS Percentiles of the Adult Employed Population

\begin{tabular}{|c|c|c|c|c|c|}
\hline Trait & & $\begin{array}{c}\text { Major } \\
\text { Executives } \\
(224)\end{array}$ & 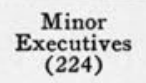 & $\begin{array}{l}\text { Others } \\
\text { (228) }\end{array}$ & $\begin{array}{l}\text { All } \\
(676)\end{array}$ \\
\hline $\begin{array}{l}\text { Intelligence } \\
\text { Supervisory qualities } \\
\text { Initiative } \\
\text { Self Assurance } \\
\text { Occupational level }\end{array}$ & : & $\begin{array}{l}75 \\
54 \\
49 \\
69 \\
75\end{array}$ & $\begin{array}{l}76 \\
52 \\
42 \\
65 \\
71\end{array}$ & $\begin{array}{l}75 \\
50 \\
36 \\
57 \\
65\end{array}$ & $\begin{array}{l}76 \\
52 \\
41 \\
64 \\
70\end{array}$ \\
\hline
\end{tabular}

faced with the task of putting new procedures into effect and of dealing with the risks involved in delegating more work to subprofessional people.

The self-assured, according to Ghiselli, are those who "attack their problems with a substantial measure of confidence, whereas others hesitate and are irresolute." 3 They are well adjusted "to problems in everyday life, especially occupational adjustment." Academic librarians seem to be rather adequately endowed with this trait. It is heartening to have an indication that college and university librarians are usually well-adjusted to their working environment. They are not usually timid and irresolute, nor chronically dissatisfied with their lot in life. This finding was confirmed by the responses received to an item on the supplementary questionnaire filled out by the respondents. Only 13 per cent expressed any regret at having chosen librarianship as a career. This proportion is much smaller than that for most other occupational groups.

That the scores of the librarians on supervisory qualities should be so low is the most disturbing finding of the survey. Despite the fact that more often than not they have supervisory responsibilities, academic librarians tend to have a different outlook on life from that of highly rated supervisors in other occupations. That the group designated as "minor executives" did not make a

Ibid., p. 4. better showing on this trait is particularly discouraging since this group was selected on the basis of the number of people supervised. Validation of this finding is contained in the answers to the supplementary questionnaire where only 2 per cent of the respondents gave supervision or personnel work as a major source of satisfaction in their work. Furthermore, among the executives, 20 per cent found supervision the least attractive aspect of librarianship.

The problem of supervisory qualities has a bearing on the recruitment of new librarians. Many of the subjects reported that having worked in a library was an important factor in their decision to enter this profession. If, then, those now supervising student assistants are inept at it or find the task distasteful, the effect will be to discourage able students from selecting librarianship as a career.

All of this does not prove that academic librarians are poor supervisors. It simply means that they frequently láck a psychological bent toward it. By using their abundant intelligence, librarians can certainly learn to do what does not come naturally. These findings add force to pleas for more formal training in the techniques of supervision and for more careful use of the talents of those who are adept at directing the work of others. For example, Winslow ${ }^{4}$ suggests sending "the new assistant to a

\footnotetext{
4Amy Winslow, "Supervision and Morale," Library Trends, III (July 1954), 48.
} 
few selected supervisors for initial training. . . ." At the same time, she wisely points out the need for "avenues of promotion for the staff member whose work merits recognition but who lacks aptitudes necessary for supervision."

The occupational level scores on the inventory are much more flattering to academic librarians than those for supervisory qualities. The outlook on life of members of the group is typical of that of other persons on about the same, rather high, occupational level. ${ }^{5}$ In general, the librarians' scores are similar to those of middle managers in other occupations. The following tabulation shows how the median scores of the three groups of librarians compare with those for other occupational categories:

Top Management personnel .

Professional personnel .

Academic Librarians (Major Executive group)

Middle Management personnel .

Academic Librarians (Minor Executive group)

Academic Librarians (Nonexecutive group)

Clerical workers

Foremen .

Skilled workers

Semiskilled workers

Unskilled workers .

The largest difference among the librarians is found between the minor executives and the nonexecutives. Many of the nonexecutive librarians tend to react to the personality test items in ways typical of white-collar workers rather than of professional or managerial personnel. This is not surprising since, by their own testimony on the supplemen-

\footnotetext{
5 Reiss estimates the socioeconomic index for librarians (all types) as 74. This compares with 84 for college presidents and professors, 73 for public Scale). He places librarians in the ninth decile of the Scale). He places librarians in the ninth decile of the population generally.-Albert J. Reiss, Occupations
and Social Status (Glencoe, III.: Free Press, c1961), pp. 263-64.
}

tary questionnaire, many of these librarians were doing considerable amounts of clerical work at the time of the survey. In the main, however, the academic librarian's view of life reflects his membership in a highly-educated strata of society. The supplemental data showed that most of the subjects came from upper-class backgrounds (sociologically speaking) and are now engaged in an occupation enjoying considerable social prestige. A small number of highly articulate respondents discussed the tendency for college and university librarians to occupy an isolated position in the academic community, but few had complaints about their status in society generally.

Results of the inventory go a long way toward finally disposing of the stereotype myth. Although as a group, the subjects show the "central tendencies" discussed above, this does not mean that they all come from the same mold or fit a common pattern. Quite the contrary. Standard deviation coefficients on all but one of the inventory scales show that there is more variety among librarians than among most other occupational groups. This finding is in agreement with those of Bryan and Douglass that heterogeneity rather than homogeneity is characteristic of librarianship. ${ }^{6}$

There are many factors involved in producing the variety of persons both needed and, fortunately, found in the academic library profession. Space here permits mentioning only a few:

Sex: The ladies will be flattered to learn that, in general, they scored higher on the personality inventory than did the men. Less encouraging is the fact that this tendency is concentrated in the lower ranks. Among the major executives, the average scores for men and

- Alice I. Bryan, The Public Librarian, A Report of the Public Library Survey (New York: Columbia University Press, 1952), p. 43. Robert R. Douglass, "The Personality of the Librarian" (abstract of Ph.D. Dissertation: Graduate Library School, University of Chicago, 1957), p. 7. 
women were alike. This may indicate that, in many cases, men with dynamic personality qualities either "go up or out"-i.e., they either rise in the profession or leave it for some other line of work. Women with vigorous personalities, on the other hand, frequently remain in the lower-salaried positions. Some of these women may not wish to assume responsibility and find the financial rewards of ordinary library work adequate to the needs of a woman without a family. Others may remain at this level despite favorable personality qualifications because the paths of advancement are simply not.open to women in either the academic or business worlds. Still others are well qualified married women whose husbands' employment determines where they shall live. They must accept whatever library employment is available there.

Age: Statistical procedures too complex to reproduce here show that personality was a more significant factor in the promotion of older than of younger librarians. This matter warrants further study to determine whether it is indeed true that, during the post-WorldWar-II years, a young man with ambition, education, and-especially-willingness to move about could become a chief librarian without much account being taken of his personality characteristics.

Type of library school: A relationship discovered between personality scores and type of library school attended by the librarian is a bit disturbing. Attendance at a high-prestige library school in a major university tended to outweigh an unfavorable score on the personality inventory. If this means that superior education has the ability to make effective leaders out of seemingly unpromising material, then it is all to the good. If it means that there has been a tendency for librarians to be appointed to high positions on the basis of the prestige of their alma maters, to the ex- clusion of other qualifications, it is a cause for concern.

Variety of experience: Mobility-i.e., ability to move to wherever opportunity lies and to acquire varied experienceis crucial to advancement in librarianship. ${ }^{7}$ The number of libraries in which a subject has worked, however, affects, and is affected by, the personality factor. For example, having favorable personality characteristics often compensates for a lack of varied experience in those seeking high-level positions. Unfortunately, the reverse is also true. Taken together, an effective personality and a good background of experience in several libraries is a combination hard to beat for the librarian with a desire to "get ahead" in his profession, in terms of either salary or position. Conversely, those lacking both personality and experience qualifications are very seldom found in the head librarian's chair of a major university.

In summary it may be said that academic librarians are an intellectually talented group whose members are well adjusted in their professional life. While their composite "personality profile" seems reasonably adequate, an ideal profile would show a shorter "tail" on the clerical end of the occupation-level curve. A better division of labor between clerical and professional staff in libraries awaits a larger supply of librarians with the inclination, aptitude, and training required for supervising the work of others. Intellectual ability will most certainly continue to be the one most important asset to the academic librarian of the future, but the complex and rapidly changing library world would benefit greatly by an infusion of more librarians with dynamic personality traits. Intelligence can devise solutions to problems, but it takes initiative to put them into effect.

${ }^{\tau}$ Data from this survey confirms previous research. See John F. Harvey, "Variety of Experience of Chief Librarians," College and Research Libraries, XIX (March 1958), 107-10. 